\title{
Research on Cultivation Mode of Application- oriented Innovative Talents Specialized in Engineering
}

\author{
Hansong Yang \\ School of Engineering \\ Huanghe Scienece and Technology College \\ Zhengzhou, China
}

\author{
Luoming Zhang \\ School of Engineering \\ Huanghe Scienece and Technology College \\ Zhengzhou, China
}

\author{
Junjie Liang \\ Henan Boda Microwave Equipment Co., Ltd. \\ Zhengzhou, China
}

\begin{abstract}
One key issue of higher education reform is how to cultivate innovative talents. The specification of social demand for talents changes continually, and at the same time, there are many problems in the teaching process of higher education. Therefore, it is particularly important to cultivate applicationoriented innovative talents specialized in engineering. In order to cultivate the innovative talents in line with regional economic development, we need to conduct reformation in curriculum system, faculty and practical teaching, to innovate teaching method, cultivate students' operation ability as well as the ability to analyze and solve the actual engineering problems, thus to meet social demand for talents.
\end{abstract}

Keywords-engineering specialty; application-oriented innovative talents; cultivation mode

\section{RESEARCH BACKGROUND}

\section{A. Social Demand for Application-oriented Innovative Talents}

With the development of machinery industry, the society and enterprises need more and more talents specialized in machinery, market demand is increasingly diverse, and higher requirements has been put forward for the quality of machinery professionals. Especially the rapid development of modern manufacturing makes the production line and grassroots units need a large number of application-oriented innovative engineering and technical personnel. Because the main objective of traditional education mode is to cultivate academic talents, so students have poor engineering consciousness after their graduation, and their engineering practical ability, operation ability and the ability to solve actual problems exist in engineering cannot meet the needs of society and production. Therefore, it is of highest priority to cultivate application-oriented innovative talents. Many colleges select part of the best undergraduate students to be involved in scientific research team and scientific research base on the basis of key laboratory, university Science Park, collegeenterprise union base or scientific and technological innovation platform, and to cultivate talents using the mode of tutorial system. The fundamental objective of the reforms on these cultivation modes is to cultivate application-oriented and innovative talents.

\section{B. Problems Exist in Education Mode of Higher Education}

As the traditional education mode takes academic talents cultivation as the main target, yet the current production line and grass-root units need a large number of applicationoriented engineering technical personnel, so the talent cultivation mode doesn't fit social demand. The research-based and academic talents only account for $10 \%-15 \%$ in higher education abroad, and all of the rest are the cultivation of application-oriented innovative talents. China has been always keeping the academic talents cultivation, especially the implementation of popular education in colleges still follows the traditional talents cultivation mode, which has revealed the following problems in the process of talent cultivation:

Incorrect positioning; obsolete teaching content, boring, and the teaching approaches, teaching methods and teaching means are too simplistic; implementation effect of practical teaching is barely satisfactory; both teachers and students lack the direct communication and interaction with society, as well as enterprise and public institution enterprises, which is unable to achieve seamless connection of talents cultivation "from school to enterprise", resulting in students suffering from the setback when they first walk out of school with low employment rate; teachers for engineering education lack the engineering background, and they pay more attention to theory yet neglect the practice, pay more attention to thesis yet neglect engineering, as a result, students lack the engineering training and application ability training; ignore the cultivation of students' comprehensive quality and innovative ability, and the excavation and cultivation of students' future career 
potential need to be further strengthened. Quite a lot of problems have revealed in the cultivation process of engineering talents, as a result, the cultivated graduates are difficult in meeting the industry's demand for talents, resulting in the increase in professional competitiveness while being unable to make the effective supply against industrial demand.

\section{Requirements of National Policies and Measures}

Cultivation of application-oriented innovative talents is an unavoidable issue of higher education. Over the past 40 years since China's reform and opening up, we have achieved remarkable great achievements in various fields. But objectively speaking, there is great gap between China and developed countries in terms of innovative ability. In particular, China is in the middle stage of industrialization, so we shall pay attention to both the cultivation of research-based innovative talents and the cultivation of large number of application-oriented innovative talents.

In order to meet the social demand for high-level and application-oriented innovative talents, China began to cultivate Master of Engineering since 1997. Due to people's prejudice toward it and the management issues, this cultivation mode and effects are unsatisfactory. Since 2009, China accelerates the transformation from academic master cultivation to professional master cultivation in terms of the development direction of postgraduate training. Some domestic brand-name colleges start to cultivate professional doctor since 2011. The fundamental purpose is to solve the engineering application ability of master and doctoral candidate, so that the cultivated students are able to meet social demand in terms of knowledge structure, professional quality and ability. As for the undergraduate training, although most of the colleges have proposed to cultivate application-oriented talents, few have really changed the cultivation mode. Therefore, there is still great gap between the applicationoriented talent cultivation of higher education and the social demand. The following table shows the talent cultivation system that has been fully implemented in higher education of undergraduate and above.

TABLE I. The CUltivation OF TALENTS

\begin{tabular}{|c|l|l|l|}
\hline Acade mic & $\begin{array}{c}\text { Undergradu } \\
\text { ate }\end{array}$ & Master of Science & Doctor of Science \\
\hline Professional & & $\begin{array}{l}\text { Professional } \\
\text { master, } \\
\text { engineering master }\end{array}$ & $\begin{array}{l}\text { Professional } \\
\text { doctor, } \\
\text { engineering doctor }\end{array}$ \\
\hline
\end{tabular}

It can be seen from the table that, the cultivation of professional undergraduate talents is exactly the current application-oriented talent cultivation, which hasn't been implemented fully, and one of the key backgrounds for this reform.

\section{SPECIFIC CONTENTS OF THE REFORM}

Construct the application-oriented innovative talent cultivation system, improve teaching system reform, take the profession and discipline as platform and construct the course group. Build the complete practice teaching system with application-oriented talent cultivation as target to cultivate innovative ability; optimize the teaching content, reform and explore new teaching methods and means, innovate assessment system, promote the overall development of students; improve teaching staff construction, strengthen the construction of double-qualified teaching staff; strengthen the cultivation of students' operation ability and the ability to solve practical engineering problems.

\section{TARGET OF PROFESSIONAL COMPREHENSIVE REFORM}

A. Construct Reasonable Cultivation System of ApplicationOriented Innovative Talents, to Cultivate the ApplicationOriented Innovative Talents with Solid Basic Knowledge, Strong Sense of Engineering, Innovative Capacity and the Ability to Solve Practical Engineering Problems

- Build the course teaching system that meet professional reform and application-oriented innovative talents, highlight the "simple, suitable and sufficient" curriculum setting, as well as the teaching resources meeting professional development in terms of resource construction.

- Construct the practice teaching system and practice teaching environment for cultivation of "innovative, application-oriented" talents. Take ability cultivation as the main line with the ability to be possessed by graduates as standards, push back the cultivation process, to build a new three-dimensional practical teaching system.

- Combine teaching management and evaluation mechanism organically, and perfect third-party evaluation system.

- Increase the cultivation of students' research and innovation ability.

\section{B. Take the Local Industry Focus as Professional Direction Characteristic to Cultivate the Application-oriented Innovative Talents Adapt to Local Economic Development}

Conduct professional talent cultivation against the needs of regional economic development with the cultivation meeting local economic development as target, and the local leading machinery industry as the carrier. Take "meeting the needs of local economic development" as purpose, strive to "develop characteristic and create the brand", to provide powerful support for the cultivation of application-oriented innovative talents for regional economic development in terms of relevant technology and talent cultivation.

\section{Construct the Excellent Double-qualified Teaching Staff}

A qualified teaching staff with high quality is necessary for teaching reform, in order to ensure the talent cultivation quality. Construct an excellent teaching staff with high theoretical level and abundant practical experience as well as more than $60 \%$ of double-qualified teachers according to the objective of talent cultivation. 


\section{MEASURES AND MEANS}

The following aspects of project construction program will be adopted to ensure smooth professional and comprehensive reform as well as the completion of ultimate goal.

\section{A. Curriculum and Teaching Resource Construction}

Strengthen curriculum system reform and construction, optimize and integrate the content of the curriculum system reasonably, to set the curriculum based on the principle of focusing on capacity cultivation, engineering consciousness, innovative ability, practical ability cultivation. Break the selfcontained pattern, realize the organic convergence of the courses, and avoid duplicate content; enrich the introduction of cutting-edge technology, and delete the obsolete content from teaching materials.

Take curriculum construction as the target to create excellent courses. Strengthen teaching resource construction and improvement. Invest in funds to purchase professional books and materials, set up new laboratory, and add experimental equipment and other teaching resources, as well as strengthen the construction of laboratory, practice base and employment base together with the enterprises. Make use of corporate resources to cooperate with enterprise closely and cultivate talents jointly.

\section{B. Reform of Teaching Methods}

The reform of teaching methods is mainly conducted in terms of the following aspects with strengthening students' ability of linking theory with practice, problem analyzing and problem solving as the objective.

1) Combination of classroom teaching and on-site teaching: Part of the courses of this profession shall be conducted in the laboratory or on the production site, to enhance students' understanding ability. Adopt the teaching method combining eyes, hands, brain and mouth, to cultivate students' practice ability to a certain degree.

2) Combine on-campus and off-campus: As for part of the course or teaching contents, take the practical projects of enterprises as carrier, and teach by putting them in enterprises, as well as explain students' problems appear in learning process using practical business case.

3) Combine theory and practice: Mechanical specialty is one the specialties that combined with production practice most closely among engineering specialties. Therefore, in teaching engineering, we shall link theoretical contents to practical engineering cases, enabling students to settle the practical problems using what they have learned.

\section{Strengthen Practical Teaching}

1) Construct three-dimensional practical teaching system: Construct a comprehensive and reasonable three-dimensional practical teaching system with actual needs and the ability to be possessed by the students as target, and the ability cultivation as main line;

2 ) Carry out the "Three Ones" activities among students: Strengthen innovative practical teaching with practical teaching environment as a platform. Carry out the "Three Ones" activity among students, that is, "a scientific paper shall be published, or a patent shall be declared, or a scientific and technological production shall be completed" before graduation.

3) Subject comes from businesses with products being used in production: In the process of practical teaching, make the masters from enterprises to guide students with the enterprise's actual product as training object, enabling students to experience the real training. Regard enterprise's actual product and projects as the topics of mechanical design, process design and graduate design, so that students can do the real subject with the common guidance of enterprise's technical staff and the teachers, to ensure students obtain a real exercise.

\section{Assessment Method Reform}

1) Conduct assessment management with curriculum system as object: Build public basic platform, discipline core platform, professional core platform curriculum group and other curriculum system for talent cultivation, conduct teaching management and appraisal with curriculum system as the object, which has broken the traditional simple course assessment as well as the organization and management methods of Department, Section and Teaching and Research Office, which is conducive to the communication, connection and assessment among the curriculum.

2) Improve third-party evaluation system: While evaluating the students, in addition to the examination of normal teaching process, the communication with employers shall be strengthened, and invite enterprises to examine students in terms of basic theory and ability, to ensure improvement of teaching quality.

\section{CONCLUSION}

Talent cultivation innovation, plan construction meeting professional cultivation as well as teaching method and means reform are the fundamental ways to cultivate applicationoriented innovation. Along with the social and economic development as well as changes in regional economy, new requirements will be raised constantly for talent cultivation.

\section{ACKNOWLEDGEMENT}

This paper is the project of off-campus practice base for national college students, experimental specialty of talent cultivation mode reform of undergraduate engineering education in regular colleges of Henan Province, and "professional comprehensive reform pilot" of institutions of higher education, and the funded projects of characteristic specialty of Henan Province and talent cultivation mode reform research project of Huanghe S\&T College.

\section{REFERENCES}

[1] Wang Ju-ying,Zhang Xiao-dong,Zhang Xiao-dong.Study and Practice of Talent Training Mode of Mechanical Specialty Based on CDIO Project Education Idea. Equipment Manufacturing Technology Vol.10, pp.218-221,2012. 
[2] Chen Guo-jin, On innovative teaching practice of engineering university students, Research and Exploration in Laboratory.Vol. 29, pp.95-97, 2010.

[3] P.Wang, Teaching reform and practicing for mechanical professionals, China juvenile, Vol. 29,pp.209,2011.

[4] Sun quan-ping,Liu yuan-wei, Research of specialty on mechanical designing-manufacturing and atomization. Higher Education forum.Vol.6,2005.

[5] Dai Xuan-jun Wu Zhi-qiang. Research on the applied talent training scheme for mechanical major in local college. Higher Education forum. Vol.6,pp.33-36,2012.

[6] Liang Ya-qin.Report on the Personnel Training of Major in Mechanical Engineering. Equipment Manufacturing Technology. Vol.1, pp.209-211, 2013. 